\title{
COMMUNICATIONS
}

\section{EXECUTIVE COMPENSATION IN MUNICIPALITIES*}

\section{INTRODUCTION}

A substantial number of all municipalities in the United States employ a city-manager as the principal operating officer rather than an elected mayor or set of elected commissioners. ${ }^{1}$ If municipalities employ city-managers to improve the economic performance $^{2}$ of local government, one might expect that the compensation of city-managers would encourage such efficiencies. That is, ceteris paribus, the more efficient the municipal government the higher we would expect the salary of the city-manager to be. If the compensation structure of city-managers does not provide managers with such financial incentives, we believe it reasonable to deduce that the council-manager form of government is not inherently more efficient

\footnotetext{
* Our research has been supported by the Center for Urban Affairs of Northwestern University, and the Manpower Administration, U.S. Department of Labor. Helpful comments from an anonymous referee, Robert Masson of the Department of Justice, and Mark Pauly, John Ledyard, and Robert Lineberry of Northwestern University are gratefully acknowledged.

${ }^{1}$ The city-manager plan has two basic components: an elected council limited by function to legislative matters and an appointed executive responsible for administration of the city. The city-manager has considerable autonomy in preparing budgets, and in the hiring and firing of personnel. In 1967 over 40 percent of cities with a population over 5,000 had a city-manager form of government. Only in the two size classifications 'under 10,000 people' and 'over 500,000 people', did less than 40 percent have a city-manager.

${ }^{2}$ In a general sense the performance of government is measured by the quantity and quality of services provided by governments. Unfortunately nowhere is measurement of performance more difficult than for services and especially the services of the public sector. For an excellent discussion of problems in this area see the paper by Mancur Olson, "Evaluating Performance in the Public Sector," the comments by C. L. Schultze, and the response by Olson in Moss (1973). Further the March 1974 issue of Social Science Quarterly (Volume $54)$ is a special issue which deals with problems of "Measuring Urban Agency Output and Performance."
}

than the alternative forms of local government.

In this paper we are concerned with the salaries of three important municipal officials; city-managers, police chiefs, and fire chiefs. We present a model that relates the salaries of these officials to a set of explanatory variables, the most important being measures associated with job performance. Two of these measures of performance are developed in the study. Further, the influence of the city-manager form of government on the incentive structure facing police chiefs and fire chiefs, and the interdependence betwen the salaries of police chiefs and fire chiefs is investigated. The model is tested using cross-section data for 1967.

\section{Related Literature}

There is an expanding literature theoretically analyzing the behavior of public officials, both elected and appointed. ${ }^{3}$ The crucial assumption in these studies is that the officeholder seeks to maximize his own utility through the actions he takes while in office. In order to exercise control over these actions without having to employ costly evaluation procedures, the people selecting the officeholders must structure the rewards in certain ways. Specifically the incentives must be such that actions desired by these people are also those actions that will lead to maximization of the officeholder's utility function. ${ }^{4}$

\footnotetext{
${ }^{3}$ See Downs [1967], Tullock [1965], Niskanen [1971], Becker and Stigler [1972], Barro [1973], McKean [1972], Alchian and Demsetz [1972].

4 Becker and Stigler [1972] is an example in law enforcement. If the compensation of an enforcer is structured so that his lifetime expected income from carrying out his duties with no malfeasance exceeds the alternatives available through malfeasance, then it is in his interests to enforce the laws and to ignore illegal inducements to 'overlook' certain criminal activities.
} 
There is no empirical work directly testing this approach for public officials. The relationship of earnings of corporate bureaucrats to firm performance has been analyzed however, and the results support the approach outlined above. Firms that relate compensation of executives to firm performance tend to perform better. ${ }^{5}$

\section{DETERMINANTS OF CITY-MANAGER, POLICE AND FIRE CHIEF SALARIES}

\section{A. City Managers}

We assume that the maximand of the citymanager is the personal rewards from office, his salary for example. ${ }^{6}$

In turn salary may be thought to be determined by two broad types of variables; (i) productivity or job performance and (ii) difficulty of the job.

The performance measures are of primary interest and we discuss them first. They include: job experience of the city-manager measured by the number of previous citymanager positions held, seniority measured by number of years at the current job, status in the ICMA, and current property tax and budget performance. City-managers are a relatively mobile class. Those who are successful tend to start in smaller cities, and move on to larger cities. ${ }^{7}$ Less successful city-

\footnotetext{
${ }^{5}$ See Masson [1971] for example. The advantage these studies have over related work on government managerial compensation is the availability of measures of firm performance. Profits, sales, and equity performance are well-defined concepts.

${ }^{6}$ The current dollar salary as reported by the International City Managers' Association (ICMA) is used as the dependent variable. The variation in real earnings across areas is discussed below. If the non-monetary rewards of office are significant, and do not vary across cities in the same manner as salaries, then use of salary as the dependent variable will lead to serious measurement error reducing the accuracy of our results. A similar caveat applies if monetary rewards exclusive of salary (future income due to current contracts developed, for example) are significant and not highly correlated with reported salaries.

${ }^{7}$ See Loveridge [1971], Kammerer et. al. [1962], and Floro [1955] for detailed discussions of city-manager mobility patterns.
}

managers, those whose performance does not satisfy local citizens, tend to change locations but stay in smaller cities. Consequently we employ two separate job experience variables in the analysis. The first (second) equals the number of previous manager positions if the city-manager is currently in a city with less than (greater than) 50,000 people and zero otherwise. Salary is expected to be negatively related to the first and positively related to the second measure of job experience.

Seniority is directly related to the way the city-manager performs his job. Presumably the longer he has been at his current job the more productive he is in the usual sense of providing output more efficiently. There is an additional dimension however that is quite important. Both Kammerer et al. [1962] and Loveridge [1971] find that citymanager tenure is lower if the city-manager is not responsive to local politicians. Length of time on the job, then, is also an indication of his ability to get along with the elected municipal officials. We postulate that salary will be positively related to seniority.

Membership or associate membership in the ICMA by an individual indicates that he has served for a period of time in one of the municipalities or councils of governments listed by the ICMA. It is a statement by the ICMA that this person is a recognized professional city-manager. This is analogous to a certificate of competence in his area. Two binary variables are used to account for status in the ICMA. The first (second) takes the value one if the individual is a member (associate member) of the ICMA and zero otherwise. We postulate that the manager's salary will be positively related to his status in the ICMA.

The final measures of performance, which are developed in this study, are concerned with total expenditures and property taxes of the municipality. We assume that local citizens are interested in the level of services provided in their community relative to other communities, and in the cost of these services relative to other communities. The 
most evident manifestation of the level of services is the size of the municipal budget. Although total spending by itself does not necessarily meet popular demands for services, most voters feel that the level of expenditures is a good indicator of the level of services being provided. ${ }^{8}$ Further, property taxes are seen as the major cost of these services. ${ }^{9}$ Accordingly, two measures of relative performance were examined: per capita property taxes and per capita total expenditures. Two regressions were estimated with property taxes per capita and total expenditures per capita as the dependent variables. ${ }^{10}$ These equations were used to predict expenditures per capita and property taxes per capita for each community. Manager performance was then measured by the difference between the actual and predicted value divided by the actual value.

The hypothesized relationship between these variables and manager salary is straightforward. In order to maximize his personal rewards the manager will push for a larger budget, since, holding property tax performance constant, a larger budget is interpreted as a higher level of services being provided. The manager does not have suf-

\footnotetext{
${ }^{8}$ See Sharkansky [1970], Niskanen [1971], and Tullock [1965] for variations of this approach. Baumol and Quandt [1964] argue that rules of thumb can be efficient economic strategies under conditions of imperfect information when decision-making is costly. It can be argued that citizens use the budget, and the level of property taxes as rule-of-thumb indicators of what level of services is being provided and at what cost.

${ }^{9}$ While property taxes are the major source of local revenue, they are not the only source. Municipalities also derive income from sales taxes, income taxes, intergovernmental transfers, fees, profits from municipal corporations, and interest on invested municipal funds. What the citizen wants is to minimize local contributions to the budget. We did attempt to estimate an equation to predict intergovernmental transfers, but no statistically significant equation could be calculated. Further the burden of sales taxes, income taxes, and fees was not clear. We therefore relied on property taxes as our indicator of costs.

${ }^{10}$ Ideally these equations should be estimated simultaneously since property taxes per capita and total expenditures (or budget) per capita are simultaneously determined. The system could not be identified. Reduced Form estimates of each equation are presented in Table I of the Appendix.
}

ficient information on the public interest to provide the exact level and mix of services that would be optimal. However the larger the budget, the more services he can provide, and hence, the more likely he is to satisfy most of the local population. There is also pressure from within the administration to expand the budget. The larger the budget, the more jobs the manager can provide and the more promotion possibilities as well. This will give him good relations with his administration, and provide members of it with little incentive to frustrate his policies so as to get him removed from office. ${ }^{11}$ Hence we postulate that salary is positively related to the budget performance variable.

Clearly the city-manager does face budget limitations, the most obvious of which is the income and debt of the community capacity. Moreover there is pressure from other communities. Voters compare the budget, the level of property taxes and their notion of services provided with similar data from other communities. If his relative performance is poor, his salary will suffer and he may lose his job. Thus we postulate that salary will be negatively related to our measure of property tax performance.

Finally, we relate salary to characteristics of the city which reflect the difficulty of the job and the resources available to pay his salary. Population size and the percentage of nonwhites in the city are proxy variables for the complexity of the job facing the citymanager. Salary is expected to be positively related to both variables. Further, two binary variables are employed to distinguish among central cities, suburban cities and independent cities, the latter being the reference group. These variables will account for systematic differences among these political units which may affect city-manager salaries.

\footnotetext{
${ }^{11}$ See Niskanen [1971] for a more extensive presentation of these arguments. It is possible to interpret the budget performance variable another way. If the actual budget per capita exceeds the 'predicted' value, this could mean that the city-manager spends more to provide the same output. This would be a sign of inefficiency, and his salary should then be negatively related to budget performance.
} 
An additional binary variable accounts for cost-of-living differences between the South and the non-South. ${ }^{12} \mathrm{We}$ expect the sign of the coefficient to be negative. Finally, we employ median house value within the community as a measure of ability-to-pay.

The data are drawn from unpublished files of the ICMA for 1967, from the 1960 Census of Population, and the 1967 Census of Governments for a sample of cities with populations greater than 25,000 people. The data for the salary and characteristics of the citymanagers are drawn from ICMA files. The information concerning population, median house value, and percentage non-white are based on the 1960 Census of Population. Finally, the performance measures are based on both the Census of Government and the Census of Population. ${ }^{13,14}$

The results of the regressions which relate salary to the explanatory variables in a simple linear form are presented in Table I.

\footnotetext{
${ }^{12}$ The South is defined to include Delaware, Florida, Georgia, Maryland, North Carolina, South Carolina, Virginia, West Virginia, District of Columbia, Alabama, Kentucky, Mississippi, Tennessee, Arkansas, Louisiana, Oklahoma, Texas.

${ }^{13}$ The dependent variable and other independent variables are based on 1967 data. Since the relevant (1967) value of the population, median house value, and percentage nonwhite variables are related to the observed (1960) values with measurement error, one can show under standard assumptions that the regression coefficients of these variables will be inconsistent estimates of the true values. (See Theil [1971], pp. 607-615) We are also assuming that the city-manager's salary in 1967 is determined after the 1967 performance measures are known. Ideally we would like to look at how different city-manager's salaries very over time in response to changes in the relative performance of their cities. The performance variables however are from the Census of Government which is published every five years.

14 "In a comparative perspective, the overwhelming evidence is that 'general municipal expenditures' is a two-dimension variable representing both the degree of functional inclusiveness and the level of municipal performance in the provision of public services." (Liebert (1974), p. 770.) The most obvious examples, but certainly not the only ones, of services for which legal responsibility varies are public education and public welfare. Our data do not permit identification of the legal responsibility assigned to each city for each service. We use total expenditures and total property taxes as reported by the Census of Government, recognizing the model specification problems due to this fragmentation of legal responsibility.
}

TABLE I

Dependent Variable: City Manager Salary

\begin{tabular}{|c|c|c|}
\hline Variable $\quad$ Co & icient & Standard Error \\
\hline Budget Performance & $1750.11^{1}$ & 365.42 \\
\hline Property tax performance & $-6.11^{3}$ & 4.27 \\
\hline \multirow{2}{*}{$\begin{array}{r}\text { Previous Positions (a) } \\
\text { (b) }\end{array}$} & $-127.55^{1}$ & 50.83 \\
\hline & $321.14^{2}$ & 161.41 \\
\hline Years at current job & $206.08^{1}$ & 38.22 \\
\hline Manager Status in ICMA & 529.30 & 886.71 \\
\hline Associate Manager Status & -1105.45 & 1018.62 \\
\hline Population (000's) & $27.63^{1}$ & 2.07 \\
\hline Percent nonwhite & $45.68^{1}$ & 19.85 \\
\hline Median House Value & $0.27^{1}$ & .05 \\
\hline South & -1713.85 & 442.21 \\
\hline Central City & $1441.28^{1}$ & 560.76 \\
\hline Suburb & $1333.77^{1}$ & 533.97 \\
\hline Constant & $11,660.96^{1}$ & 1072.18 \\
\hline
\end{tabular}

$N=289$

$R^{2}=0.63$

$F=35.32$

1. Significant at the 1 percent confidence level using a one-tailed test.

2. Significant at the 5 percent confidence level using a one-tailed test.

3. Significant at the 10 percent confidence level using a one-tailed test.

With the exception of the coefficients of the ICMA status variables, which are statistically insignificantly different from zero, all the coefficients have the expected signs. Citymanager salary is positively related to the budget performance variable and negatively related to the property tax performance variable as postulated..$^{15}$ In a city, where the property tax performance variable is one standard deviation below the mean for the sample, the city-manager receives 260 dollars more than the city-manager in a city in which property tax performance is average. Similarly if the budget performance variable is one standard deviation above the sample mean, he receives 875 dollars more than the

\footnotetext{
${ }^{15}$ When the same regression is calculated using salary defleted for cost of living differences across cities, as the dependent variable, the coefficient of the binary variable for the South is statistically insignificantly different from zero. Otherwise the results do not change. Similarly, the results are qualitatively the same when the natural logarithm of salary is used as the dependent variable.
} 
APPENDIX

TABLE I

Total Expenditure Per Capita and Property Tax Per Capita Regressions ${ }^{|1|}$ Total Expenditure Per Capita

Property Tax Per Capita

\begin{tabular}{lcccc}
\hline \multicolumn{1}{c}{ Variable } & Coefficient & $($ Standard Error) & Coefficient & (Standard Error) \\
Population (000's) & 0.20 & $(.05)$ & 0.09 & $(0.02)$ \\
[Population (000's) $]^{2}$ & $-0.09 \times 10^{-3}$ & $\left(.04 \times 10^{-3}\right)$ & $-0.05 \times 10^{-3}$ & $\left(0.01 \times 10^{-3}\right)$ \\
Median House Value & $0.02 \times 10^{-1}$ & $\left(0.01 \times 10^{-1}\right)$ & $0.02 \times 10^{-1}$ & $\left(0.03 \times 10^{-2}\right)$ \\
Percent Nonwhite & 0.49 & $(0.39)$ & 0.27 & $(0.13)$ \\
Central City & -16.98 & $(10.76)$ & -4.61 & $(3.46)$ \\
Suburb & -34.88 & $(11.15)$ & -4.27 & $(3.59)$ \\
New England 2] & 102.86 & $(15.46)$ & 73.94 & $(4.98)$ \\
South Atlantic & -52.37 & $(12.42)$ & -44.91 & $(4.02)$ \\
East North Atlantic & -61.10 & $(16.48)$ & -52.10 & $(5.33)$ \\
East South Atlantic & -11.99 & $(15.25)$ & -43.53 & $(5.18)$ \\
West North Central & 75.69 & $(20.06)$ & -59.71 & $(6.49)$ \\
West South Central & -76.89 & $(15.93)$ & -57.48 & $(5.32)$ \\
Mountain & -70.79 & $(20.29)$ & -62.79 & $(6.64)$ \\
Pacific & -44.09 & $(14.06)$ & -58.74 & $(4.86)$ \\
Constant & 160.81 & $(17.96)$ & 58.03 & $(5.80)$ \\
& & & & \\
\hline$R^{2}=0.29 \quad F=18.37$ & $N=656$ & & & \\
$R^{2}=0.66 \quad F=81.48$ & $N=656$ & & &
\end{tabular}

[1] The variables presented in Table I are those which yield the best overall results. Other variables used in early calculations but not entered in the final regressions include; median income, percent of the population with greater than $\$ 10,000$ income, median education, and percent of the population under 18 . The simple correlation between median house value and median income, in the sample, is 0.82 .

[2] The reference group for the set of regional binary variables is the Middle Atlantic.

city-manager in a city in which the performance is average, cet. par. ${ }^{16}$

Although the coefficients of these two variables have the predicted signs, the results indicate that population, and job experience are the most important explanatory variables. As argued above the job experience variables are important measures of performance, and it is clear then that good performance leads to a higher salary. The "previous positions" variables for example, support the hypothesis that the more successful citymanagers tend to change locations moving

${ }^{16}$ The mean of the property tax performance variable is -2.78 ; the standard deviation, 42.51 . The mean of the budget performance variable is -0.20 ; the standard deviation, 0.50 . The average city-manager salary in the sample is 19,870 dollars. among larger cities. They are rewarded for perceived performance in their past jobs by their existing employers. Movement among smaller cities on the other hand would appear to be an indication of poor performance, and compensation is structured to reflect this.

\section{B. Police and Fire Chiefs}

We now examine the determinants of police and fire chiefs' salaries. The current dollar salaries of the two, as reported by the ICMA for 1967, are used as dependent variables in separate regressions, one for fire chiefs, the other for police chiefs.

Since there are no data available on the personal characteristics of these municipal executives, the explanatory variables we uti- 
lize can be divided into only two classes; job performance and characteristics of the city. The measures of performance for fire and police chiefs are similar to those used for city-managers. For the police department, a measure of performance based on the crime index reported by the FBI was calculated; for the fire department, one based on the city ratings used for insurance purposes. ${ }^{17}$

To derive the measure of police department performance, we first estimated a regression with the crime index as the dependent variable. The measure of performance is then the actual crime index minus the predicted crime index divided by the actual crime index for the city in question. Similarly, a regression was calculated with the fire insurance classification as the dependent variable. ${ }^{18}$ The measure of performance of the fire department is the actual fire insurance classification minus the predicted fire insurance classification divided by the actual classification. The salary of the police chief (fire chief) is expected to be positively related to the performance of his department, that is, negatively related to the constructed performance variable.

The variables describing the city are identical to those used in the previous section, with the addition of a binary variable taking the value one if there is a city-manager form of government, and a binary variable taking the value one if there is a commission form of government. The reference group for these

\footnotetext{
${ }^{17}$ The crime index has been used by Votey and Phillips [1973] in a study of the effectiveness of police activity, and by Ehrlich [1973] in a study of the deterrent effect of criminal law enforcement. As is well known, this index is subject to substantial measurement error across cities. Ahlbrandt [1973] in his study of the efficiency of fire departments uses cost per capita as his dependent variable. He uses an index based on the fire insurance classification to reflect quality differences between fire departments. A city's rating is poorer the more points it has. Points of deficiency are assessed against a city when conditions are below standards prescribed in a schedule set up by the American Insurance Association. Both the crime indices and the fire insurance classifications are provided by the ICMA for 1967 .

${ }^{18}$ The underlying regressions for the crime index and the fire insurance classification are reported in Table II of the Appendix.
}

two binary variables is the mayoral city. These variables are entered to control for differences among forms of government.

While the sample of cities analyzed above was restricted to those with a city-manager form of government, we extend our analysis of fire and police chiefs to include mayoral and commission forms of government. Consequently we are able to test whether the relationship between the compensation of the police (fire) chief and the performance of his department is affected by the form of government. There are two variables for each regression. In the police (fire) chief regression the first interaction variable equals the constructed police (fire) department performance variable if the city has the city-manager form of government and zero otherwise. Similarly, the second variable equals the constructed police (fire) department performance variable if the city has the commission form of government and zero otherwise. If the coefficient of the first (second) interaction variable is negative, while the coefficient of the performance variable alone is statistically insignificant, we can infer that the city-manager (commission) form of government provides an incentive for the police (fire) chief to improve his department's performance, while the mayoral form of government does not. This suggests that the city-manager (commission) form of government is more effective in improving the performance of the police and fire departments. If both the interaction variable and the performance variable alone have negative signs, then we can infer only that the city-manager (commission) form of government provides a higher marginal reward for improvements in the performance of the police (fire) department. Finally if the interaction variable has no significant effect, while the performance variable alone has a negative coefficient, then the city-manager (commission) and mayoral forms of government provide the same incentives to the police (fire) chief to improve the performance of his department.

Ordinary least squares regressions were estimated for police chiefs and fire chiefs sepa- 
rately. The results are presented in Table II. The salary of the police chief is negatively related to our police department performance variable, as hypothesized. ${ }^{19}$ The form of government however, does not affect this relationship; that is, the coefficients of the interaction variables are not statistically significant. In the case of the fire chief, on the other hand, the form of government is important. The salary of the fire chief is negatively related to the fire department's performance in city-manager cities only. There is no statistically significant relationship be-

\footnotetext{
19 'Performance' in all cases means the performance variable constructed in this study.
}

tween the fire department's performance and the fire chief's salary under the mayoral or commission form of government.

\section{Interdependence of Police and Fire Chief Salaries}

Due to the nature of municipal politics, and the similarity of these two jobs it is reasonable to expect that the police chief's and fire chief's salaries will be interdependent. To test this hypothesis a two-equation system was estimated by three stage least squares. The reduced form estimates of these equations are presented in Table III; the structural coefficients, in Table IV.

In the reduced form equations, presented

TABLE II

Police and Fire Chief Salary Regressions

(Ordinary Least Squares Assuming Independence From Other Category's Salary)

Police Chief Results

Fire Chief Results

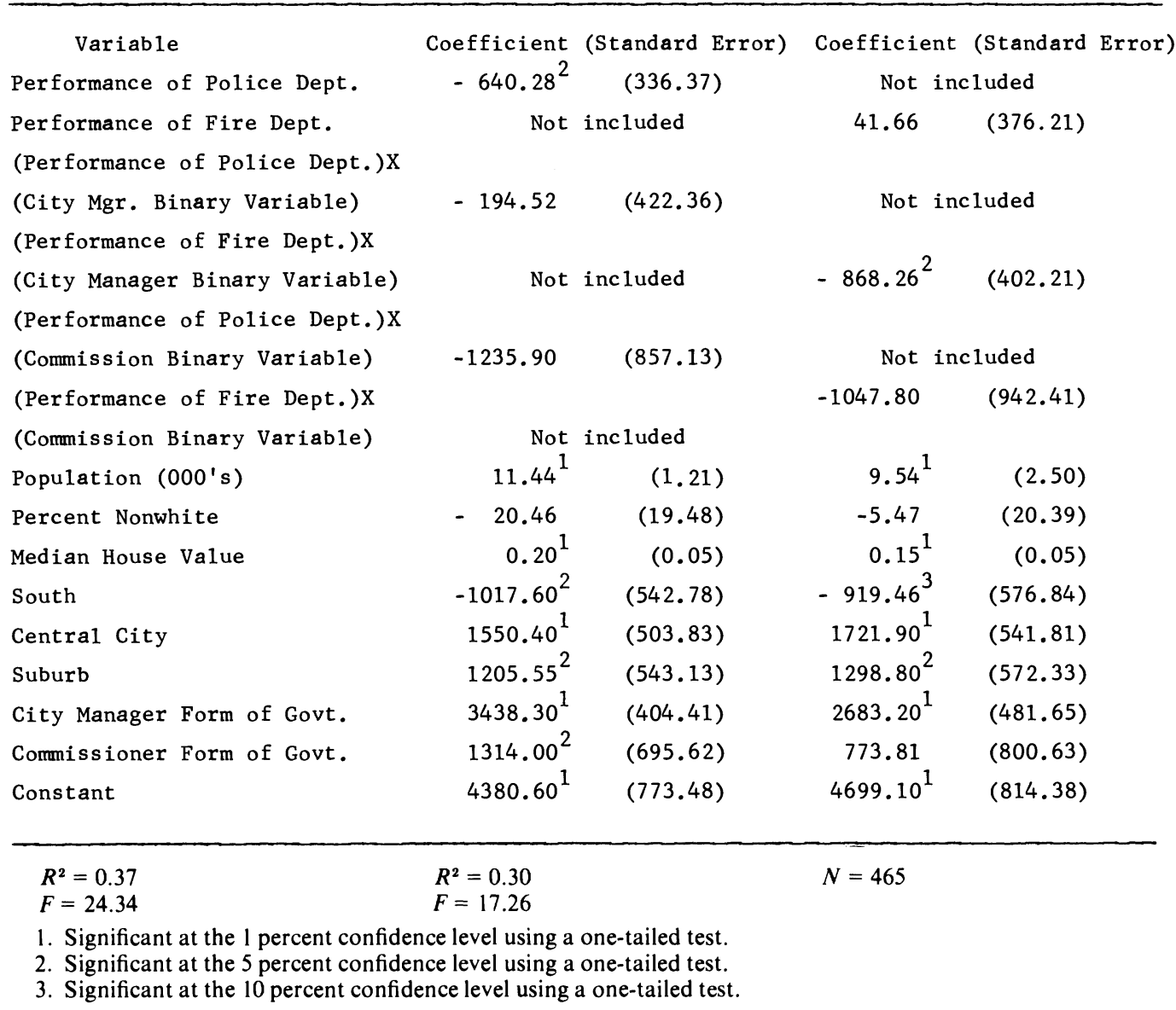




\begin{tabular}{|c|c|c|c|c|}
\hline CRIME INDE & $\begin{array}{l}\text { AND FIRE IN } \\
\text { Crime In }\end{array}$ & $\begin{array}{l}\text { APPENDIX } \\
\text { TABLE II } \\
\text { NSURANCE CLASSIFICATIO } \\
\text { deX }\end{array}$ & $\begin{array}{l}\text { N REGRESSIONS } \\
\text { Fire Insuranc }\end{array}$ & Classification \\
\hline Variable & Coefficient & (Standard Error) & Coefficient & (Standard Error) \\
\hline Population (000's) & 36.12 & $(1.50)$ & 0.80 & $(0.12)$ \\
\hline$\left[\text { Population }\left(000^{\prime} s\right)\right]^{2}$ & $-\quad 5.75$ & $(9.05)$ & 0.35 & $(0.78)$ \\
\hline Land Area (Square Miles) & -0.04 & $(0.02)$ & Not inc & 1uded \\
\hline Population (000's) per Sq.Mi & Not & included & $-0.02 \times 10$ & $\left(0.03 \times 10^{-2}\right)$ \\
\hline Percent Nonwhite & 15.58 & $(10.79)$ & -0.44 & $(0.99)$ \\
\hline Percent under 18 & -28.14 & $(20.93)$ & 3.80 & $(2.33)$ \\
\hline Median Education & -230.47 & $(130.28)$ & Not inc & luded \\
\hline Percent with Greater than & & & & \\
\hline 10,000 Income & 13.47 & $(15.26)$ & Not inc & luded \\
\hline Percent of Single Family & & & & \\
\hline Units Owner Occupied & Not & included & 2.49 & $(1.09)$ \\
\hline Median House Value & Not & included & $-0.53 \times 10^{-2}$ & $\left(0.25 \times 10^{-2}\right)$ \\
\hline Central City & Not & included & -116.81 & $(25.10)$ \\
\hline Suburb & Not & included & -44.35 & $(28.67)$ \\
\hline New England & -148.66 & $(1047.20)$ & -67.67 & $(95.22)$ \\
\hline South Atlantic & -512.42 & $(341.00)$ & -26.51 & $(31.06)$ \\
\hline East North Central & 213.97 & $(392.26)$ & 16.13 & $(33.46)$ \\
\hline East South Central & 488.49 & $(365.82)$ & -42.63 & $(33.47)$ \\
\hline West North Central & 6.43 & $(496.03)$ & 3.03 & $(44.58)$ \\
\hline West South Central & 194.56 & $(527.53)$ & 64.20 & $(45.33)$ \\
\hline Mountain & 686.45 & $(466.38)$ & 54.41 & $(40.69)$ \\
\hline Pacific & 722.76 & $(300.30)$ & -172.83 & $(26.30)$ \\
\hline Constant & 2261.80 & $(1572.30)$ & 576.39 & $(97.36)$ \\
\hline $\begin{array}{l}R^{2}=0.86 \\
R^{2}=0.43\end{array}$ & $\begin{array}{l}F=171.2 \\
F=21.2\end{array}$ & & $\begin{array}{l}N=465 \\
N=465\end{array}$ & \\
\hline
\end{tabular}

in Table III, we see that in city-manager cities, the salaries of both municipal executives are negatively related to the performance of both departments. This highlights the interdependence between the salaries of the fire and police chiefs. Under the mayoral and commission forms of government however, the salaries of the two executives are negatively related to the police department performance variable only. Consequently, the form of government is a significant factor affecting the relationship between the salaries of the two municipal executives and the performance variables of their departments. Under the city-manager form of government, there is an incentive for these two municipal executives to improve the performance of both departments. Under the other forms of government, there is an incentive to improve the performance of the police department only. Finally in the structural equations presented in Table IV, the magnitude of the interrelation between the salaries of the police chief and the fire chief can be seen. Ceteris paribus the fire chief's salary increases 89 cents for every 1 dollar increase 
TABLE III

Police and Fire Chief Salary Regressions

(Reduced Form Coefficients Assuming Interdependence with Other Chief's Salary)

\begin{tabular}{|c|c|c|c|c|}
\hline & & lice Chief Results & Fire Chi & ef Results \\
\hline Variable & Coefficient & (Standard Error) & Coefficient & (Standard Error) \\
\hline Performance of Police Dept. & $-669.81^{2}$ & $(336.03)$ & $-843.25^{1}$ & $(351.43)$ \\
\hline $\begin{array}{l}\text { Performance of Fire Dept. } \\
\text { (Performance of Police Dept.)X }\end{array}$ & 190.72 & $(357.82)$ & 4.50 & $(374.22)$ \\
\hline $\begin{array}{l}\text { (City Mgr. Binary Variable) } \\
\text { (Performance of Fire Dept.)X }\end{array}$ & -97.85 & $(424.32)$ & 298.28 & $(443.78)$ \\
\hline $\begin{array}{l}\text { (City Mgr. Binary Variable) } \\
\text { (Performance of Police Dept.) X }\end{array}$ & $-794.29^{2}$ & $(383.89)$ & $-800.61^{2}$ & $(401.49)$ \\
\hline $\begin{array}{l}\text { (Commission Binary Variable) } \\
\text { (Performance of Fire Dept.)X }\end{array}$ & -1106.60 & $(863.89)$ & -828.24 & $(903.49)$ \\
\hline (Commission Binary Variable) & -765.33 & $(900.91)$ & -785.61 & $(942.21)$ \\
\hline Population (000's) & $12.08^{1}$ & $(2.37)$ & $9.09^{1}$ & $(2.48)$ \\
\hline Percent Nonwhite & -23.30 & $(19.54)$ & -15.16 & $(20.44)$ \\
\hline Median House Value & $0.20^{1}$ & $(0.05)$ & $0.14^{1}$ & $(0.05)$ \\
\hline South & $-867.85^{3}$ & $(546.75)$ & $-1073.70^{2}$ & $(571.82)$ \\
\hline Central City & $1297.00^{1}$ & $(515.94)$ & $1804.40^{1}$ & $(539.59)$ \\
\hline Suburb & $1186.90^{2}$ & $(541.57)$ & $1283.80^{2}$ & $(566.40)$ \\
\hline City Manager Form of Govt. & $2985.70^{1}$ & $(457.47)$ & $2726.50^{1}$ & $(478.45)$ \\
\hline Commissioner Form of Govt. & $989.78^{3}$ & $(766.93)$ & $990.36^{1}$ & $(802.08)$ \\
\hline Constant & $4576.20^{1}$ & $(775.63)$ & $5013.30^{1}$ & $(811.19)$ \\
\hline $\begin{aligned} R^{2} & =0.38 \\
F & =19.65\end{aligned}$ & $\begin{aligned} R^{2} & =0.32 \\
F & =14.84\end{aligned}$ & & $N=465$ & \\
\hline
\end{tabular}

in the police chief's salary, while the police chief's salary increases 85 cents for every 1 dollar increase in the fire chief's salary.

\section{CONCLUSION AND IMPLICATIONS FOR FUTURE RESEARCH}

In this study we investigated the relationship between the salaries of three important municipal executives, city managers, police chiefs and fire chiefs, and constructed measures of their "performance". Our empirical results tend to support the hypothesis that the rewards received by these executives are positively related to our constructed meas- ures of their performance. Further, we found that the incentive structure designed to support certain policy goals is affected by the form of government. The city-manager form of government provides salary rewards for less crime and improved fire department ratings; the mayoral and commission forms of government reward less crime. Clearly, further research would seek to identify other measures of performance which are related to the salaries of these executives.

The empirical results for city-manager compensation are especially important because of their relevance to the debate on the optimal organization of municipal govern- 
TABLE IV

Police and Fire Chief Salary Regressions

(Structural Coefficients Assuming Interdependence with Other Chief's Salary)

Police Chief Results

Fire Chief Results

\begin{tabular}{|c|c|c|c|c|}
\hline Variable & Coefficient & (Standard Error) & Coefficient & (Standard Error) \\
\hline Police Chief Salary & \multicolumn{2}{|c|}{ Not included } & .89 & $(.14)$ \\
\hline Fire Chief Salary & 0.85 & $(0.19)$ & Not & included \\
\hline Performance of Police Dept. & -155.70 & $(203.26)$ & Not & included \\
\hline $\begin{array}{l}\text { Performance of Fire Dept. } \\
\text { (Performance of Police Dept.)X }\end{array}$ & \multicolumn{2}{|c|}{ Not included } & 0.49 & $(99.42)$ \\
\hline (City Mgr. Binary Variable) & -31.38 & $(120.67)$ & Not & included \\
\hline $\begin{array}{l}\text { (Performance of Fire Dept.)X } \\
\text { (Performance of Police Dept.)X }\end{array}$ & \multicolumn{2}{|c|}{ Not included } & -185.77 & $(213.85)$ \\
\hline $\begin{array}{l}\text { (Commission Binary Variable) } \\
\text { (Performance of Fire Dept.)X }\end{array}$ & -272.37 & $(307.42)$ & \multicolumn{2}{|c|}{ Not included } \\
\hline (Commission Binary Variable) & Not inc & cluded & -186.55 & $(303.63)$ \\
\hline Population (000's) & 3.24 & $(1.97)$ & -0.71 & $(1.93)$ \\
\hline Percent Nonwhite & -9.23 & $(10.87)$ & 4.33 & $(11.15)$ \\
\hline Median House Value & 0.08 & $(0.04)$ & -0.04 & $(0.04)$ \\
\hline South & 7.58 & $(379.04)$ & -259.86 & $(326.59)$ \\
\hline Central City & -237.45 & $(482.68)$ & 652.93 & $(333.43)$ \\
\hline Suburb & 67.46 & $(389.46)$ & 252.35 & $(350.38)$ \\
\hline City Manager Form of Govt. & 710.79 & $(652.76)$ & 23.33 & $(474.00)$ \\
\hline Commissioner Form of Govt. & 201.01 & $(453.91)$ & 59.76 & $(422.44)$ \\
\hline Constant & 339.39 & $(1018.50)$ & 879.69 & $(737.71)$ \\
\hline
\end{tabular}

ment. An important extension to our research would therefore be to mayoral reelection data in mayor-council cities. Is the probability of reelection of the mayor influenced by the same factors that affect the city manager's salary? ${ }^{20}$ If this probability is similarly influenced by these performance measures, there would then be no reason to expect cities run by city managers to have municipal services produced more efficiently than cities run by elected mayors.

\section{Northwestern University}

GERALD S. GOLDSTEIN

\section{Cornell University}

\section{RONALD G. EHRENBERG}

\footnotetext{
${ }^{20}$ There are unfortunately no data currently available on mayoral reelections.
}

\section{REFERENCES}

1. Ahlbrandt, R., "Efficiency in the Provision of Fire Services," Public Choice, 16 (1973), 2-15.

$\rightarrow$ Alchian, A.A. and Demsetz, H., "Production, Information Costs, and Economic Organization," American Economic Review, 62 (1972), 777-796.

3. Barro, R., "The Control of Politicians: An Economic Model," Public Choice, 14 (1973), 1-42.

4. Becker, G. S. and Stigler, G. J., "Law Enforcement, Corruption, and Compensation of Enforcers," Prepared for the Conference on Capitalism and Freedom, Charlottesville, Va. (1972).

$\rightarrow$ Baumol, W. J. and Quandt, R. E., "Rules of Thumb and Optimally Imperfect Decisions," American Economic Review, 54 (1964), 23-46.

6. Downs, A. Inside Bureaucracy (Boston: Little, Brown and Co., 1967).

7. Ehrlich, I., "The Deterrent Effect of Criminal Law Enforcement," Journal of Legal Studies, I (1973), 259-277.

$\rightarrow$ Farrell, M. J., "The Measurement of Productive Efficiency," Journal of the Royal Statistical Society, 
Series A, 120 (1957), 253-281.

9. Fisk, D. M. and Winne, R. E., "Output Measurement in Urban Government: Current Status and Likely Prospects," Social Science Quarterly, 54(1974), 725-740.

10. Floro, G. K., "Continuity in City Manager Careers," American Journal of Sociology, 61 (1955), 240-46.

11. Fuchs, V. R., ed. Production and Productivity in the Service Industries, Studies in Income and Wealth, No. 34 (New York: National Bureau of Economic Research, 1969).

12. Kammerer, G. M., et. al. City Mangers in Politics: An Analysis of Manager Tenure and Termination, University of Florida Monographs in the Social Sciences, 13, (1962).

13. Liebert, R., "Municipal Functions, Structure and Expenditures: A Reanalysis of Recent Research," Social Science Quarterly, 54(1974), 765-783.

$\rightarrow$ Lewellen, W. G. and Huntsman, B., "Managerial Pay and Corporate Performance," American Economic Review, 60 (1970), 710-721.

15. Loveridge, R. O. City Managers in Legislative Politics (Indianapolis: The Bobbs-Merrill Co., Inc., 1971).
16. Masson, R. T., "Executive Motivations, Earnings and Consequent Equity Performance," Journal of Political Economy, 79 (1971), 1278-1293.

17. McKean, R. N., "Property Rights Within Government and Devices to Increase Governmental Efficiency," Southern Economic Journal, 39(1972), pp. 177-186.

18. Moss, Milton, ed. The Measurement of Economic and Social Performance, Studies in Income and Wealth, No. 38 (New York: National Bureau of Economic Research, 1973).

19. Niskanen, W. A. Bureaucracy and Representative Government, (Chicago: Aldine-Atherton, 1971).

20. Schmandt, H. J. and Stephens, G. R., "Measuring Municipal Output," National Tax Journal, 13 (1960), 369-375.

21. Sharkansky, I. Public Administration (Chicago: Markham, 1970).

22. Theil, H. Principles of Econometrics (New York: John Wiley and Sons, Inc., 1971).

23. Tullock, G. The Politics of Bureaucracy (Washington, D. C.: Public Affairs Press, 1965).

24. Votey, H. L. and Phillips, L., "Police Effectiveness and the Production Function for Law Enforcement," Journal of Legal Studies, 1(1973), 423-436. 